\title{
Domestic Violence Inducing Females' Gynecological and Urological Problems: The Forensic and Social Perspectives
}

\author{
Abo Elyazied A. Fouad ${ }^{1,2}$, Sayed Ibrahim Ali3 ${ }^{3,4}$, Mohamed Gaber Soliman ${ }^{5}$ and Amira Okoud Osman ${ }^{6}$ \\ ${ }^{1}$ Department of Forensic Medicine and Clinical Toxicology, Faculty of Medicine, Tanta University, Tanta, Egypt. \\ ${ }^{2}$ Department of Biomedical Science, Division of Forensic Medicine, College of Medicine, King Faisal University, Al-Ahsa, \\ Saudi Arabia. \\ ${ }^{3}$ Department of Family and Community Medicine, College of Medicine, King Faisal University, Al-Ahsa, Saudi Arabia. \\ ${ }^{4}$ Department of Educational Psychology, College of Education, Helwan University, Cairo, Egypt. \\ ${ }^{5}$ Department of Urology, Faculty of Medicine, Tanta University, Tanta, Egypt. \\ ${ }^{6}$ Department of Gynecology and Obstetrics, College of Medicine, King Faisal University, Al-Ahsa, Saudi Arabia.
}

\begin{abstract}
Background: Domestic violence is a major health and social issue. Forensic documentation of this problem might be of great significance. This study aims to define the primary forensic and social features of domestic violence.

Materials and Subjects: The study materials consisted of 779 Saudi Arabian females, aged 15-60 years, attending the gynecology, and urology clinics at three secondary health centers in the Eastern Province, Saudi Arabia. A self-administrated questionnaire was employed in this study, which entails two scales to cover both forensic and social aspects of the assault. The SPSS/PC software package for version 25.0 was utilized to perform the statistical analysis.

Results: During the study period, 950 women have attended the clinics with (82\%) response rate. The percentage of physical violence was higher than the other forms (75\%). The highest incidence of domestic violence (42.6\%) was in the age group (20-30) and in married women. The frequency of abusing shows a significantly higher percentage of occasional answers (75.68\%).The most commonly reported injury sites were the head (45.27\%). Slaps/ push were the sorts of violation in (56.4\%) of cases. Husbands (57.4\%) were the main perpetrators. Six gynecological and urological symptoms were significantly more common in women with a history of domestic violence.

Conclusion: The results of this work denoting the great importance of forensic practicing in the era of domestic violence investigations. Medicolegal researches should be considered as a cornerstone in the programs designed for proper reporting, and prevention of violence against women.
\end{abstract}

Key words: Medicolegal, Domestic violence, Gynecological, and urological.

\section{Introduction}

$\mathrm{T}$ The current definition of domestic violence according to The World Health Organization's (WHO) including the physical acts, threat isolation, sexual compulsion, emotional abuse as well as limiting approximation to health attention or fiscal resources (Abramsky et al.,2011).Worldwide, domestic violence is a popular and substantial matter. Violence contra girls and women is considered as a prime health and human rights import. Women may expertise physical or mental insult through all stages of their life (Akadli et al., 2013).

Domestic violence does not motivate any global appointed interest until the late 1960s, when the society considered violence within the house is a particular issue. During the 1980s and 1990s, domestic violence became one of the major under-reported offenses, which are openly renowned. As the years pass, domestic violence has been as not only a serious and inadmissible public 
conduct but a major overburden on the health order at the global standard as well (Boyle et al., 2009).

Principally, any woman regardless of the social or economic situation may suffer domestic violence even with a variety of factors in various areas of the world but those living in poorness are potential to experience violence (Haj-Yehyia et al., 2012). Moreover, women are victims of domestic force at a rate nearly five times if compared to males. In the United States, domestic violence is more eminent among women aged 16 to 24 (Saltzman et al., 2003). Domestic violence is recorded predominantly in women with a low educational level. In addition, women suffering from physical or mental diseases were on rate influenced by domestic violence much more than others (Rickert et al., 2002 and Saltzman et al., 2003).Additionally documented domestic abuse is more prevalent among housewives if compared with the employees (Rickert et al., 2002).

In spite of being a critical problem, violence is still a covert issue in Islamic and Arabic countries, as most victims of abuse did not converse health care provisioner about the correct origin of their injuries (Tashkandi and Rasheed, 2009). There are many factors attributed to the high rate of unreported domestic violence cases in Saudi Arabia and many other countries such as unawareness of women's rights, social attitude, and conventionalism. In addition, the high grade of families' privacy is an important factor for escaping detection of many offense cases (Ahmad, 2016).

Domestic violence is distributing as physical, sexual and emotional (psychological). Beating, slapping, hitting, and kicking are common forms of physical abuse. These are deemed as moderate physical abuse (Borchers et al., 2016) while hitting, kicking, dragging, threatening or attacking by a weapon are considered as a severe physical assault (Amanda ,2018). On the other hand, sexual violence comprises forcible sexual act or any way of sexual compulsion. Affronts, disparaging, constant indignity, intimidation are believed as a labor of emotional (psychological) insult (Jury et al., 2017).

Elevated anxiety level, great depressive upsets together with psychological distress are exceedingly common in women who have the expertise to abuse. Among abused women, gynecological troubles are shown to be in most agreement as it were three times utmost if compared to the non-abused cases (Jury et al., 2017 and Sedziafa et al.2017). Moreover, Victims of domestic violence are more likely to experienced augmented medical and emotional upsets following a physical assault. Along the literature, victims of abuse presented a significantly high rate of non- definite gastrointestinal and or urinary manifestations (Heim et al., 2000 and Sedziafa et al.2017).

\section{Aim of the work}

This study aiming to define the primary forensic and social features of domestic violence in a sample of Saudi Arabia females who are attending the secondary health care centers in Eastern Province of Saudi Arabia.

\section{Materials and Subjects}

In the study, 950 Saudi Arabian females who sought medical care were seen in the gynecological and urological clinics throughout the period from January 2017 to January 2018. We defined 15 to 60 years old as an eligible age for participation. Three secondary health centers in the Eastern Province, Saudi Arabia were the locations of our cross section prospective study.

Informed consent for participation in this study was gained from each participant after clear explanation for the aim of the study and the details of the questioner. For participants aged less than 18 years, informed consent was taken from their parents or guardians. The expected public benefits for this research were pointed out. The right to refuse participation in the study was secured for all without requiring for reasons. No health, social nor family riskiness would be enjoined on participants. Complete confidentiality of the information was assured. Following that, the approval of the local ethics committee of our institute was obtained.

At each study location, Women were met in the clinics' waiting zones. They were invited alone without any accompanying persons to a separate compartment for vital signs assessment, weight estimation, and to respond to the questionnaire.

The questionnaire exercised in this work was designed to compile the different aspects of domestic violence (Crane et al., 2000, Swahnberg and Wijma 2003, and Kotelchuck 2006,). It entitled two sections: the first one shows questions about the demographic characteristics of the women (age, marital state, level of education, occupation status, pregnancy status, number of children, history of chronic diseases and drugs used for it). The first part also contains questions about the partners (level of education, smoker or not, monthly household income, history of previous custody, employment status, history of chronic diseases and drugs used for it).

The second section consists of questions about the form of abuse they suffered from (physical, verbal, emotional, sexual) and the sort of trauma they faced (slap/push, punch, kick, burns, wounds inflicted by objects), whether the insult resulting in hospital admission or permanent infirmity. The frequency and duration of abuse (very often, sometimes, occasionally), whether they seeking help or not and the approach of seeking such help (in case of answering yes) were asked.

The second part involves questions about the injured sites (head, chest, abdomen, extremities), the probable perpetrator (father, husband mother, siblings, others) and ten common gynecological and five urological manifestations. The definitions of those manifestations were explained in such simple and clear manner.

The SPSS/PC software package for version 25.0 was employed to perform the statistical analysis. Adjective statistics were applied to epitomize the characteristics of cases sorted as positive or negative for 
domestic violence and then expressed as numeral values and percentages. The variables were charted according to the abuse set and the non-abused set. Chi-squares test was exercised to quantify each variation in the demographic data among the two sets. The relation between domestic violence cases with the various gynecological and or urological manifestations mentioned in the questionnaire was determined by Chisquares test. Significance was adopted at $\mathrm{p}<0.05$ for interpretation of results of tests.

\section{Results}

(Dawson and Trapp, 2001).

During the study period, 950 women have attended the clinics, 171 out of them (18\%) were unwilling to participate in the study. The response rate was $82 \%$. Out of 779 participants, 148 women (18.99\%) gave a history of domestic violence. Figure (1) demonstrates the prevalence and forms of violence for the participants. The percentage of physical violence was higher than the other forms (75\%), while the lowermost one was sexual violence $(2.03 \%)$ with a statistically significant result $(\mathrm{P}=$ $0.0001)$

Socio-demographic data of women with and without history of abuse were collated. The participants were divided in relation to their age group. Age group (20-30) shows the highest incidences of domestic violence (42.6\%). Among all the socio-demographic data: married women, intermediate level of education, and housewives position were pointed out to be probable risk factors for domestic violence (56\%, 40.5\% and, $43.9 \%$ respectively) with statistically significant result ( $\mathrm{P}$ $<0.05$ ) (Tables 1-3).

Tables (4\&5) demonstrates the sociodemographic data of the partners. The highest incidences of domestic violence. (45.9\%) was in partners' age group (20-30) .The Elementary and intermediate levels of education, low income, as well as private employment were found to be probable risk factors for violence with a statistically significant result. $(\mathrm{P}<0.05)$

As illustrated in (Table 6), the frequency of abusing shows a significantly higher percentage of occasional answers (75.68\%) with a statistically significant result $(\mathrm{P}=0.0001)$. Only 43 cases $(29.05 \%)$ out of the 148 total participants with a history of abuse were seeking help. Their families were the approach of help in (79.07\%).Only two cases (4.65\%) were progressed to have legal and or medicolegal consequences.

Regarding the topographic distribution of injuries, the most commonly reported injury sites were the head (45.27\%) while the lowest percentage was for the neck injuries (12.84\%). This result also shows a statistically significant impact $(\mathrm{p}=0.0001)$ (Figure 2).

Slaps/ push were the sorts of violation commonly announced (56.4\%) followed by punch and kick (42.7\%), the lowest percentage belongs to burns and scalds $(11.8 \%)$ with a statistically significant result $(\mathrm{p}=$ $0.0001)$. Four cases (3.6\%) had been admitted to the hospital for their trauma and only one case $(0.9 \%)$ gave a history of permanent injury. (Table 7).

Husbands (57.4\%) and fathers (24.3\%) were the main perpetrators while mothers constitute (11.5\%). Siblings and other relatives were represented by the same percentage (9.46\%). This result displays a statistically significant impact $(\mathrm{p}=0.0001)$ (Table 8).

From the fifteen gynecological and urological symptoms included in the questioner, only six symptoms (Vaginal bleeding, dysmenorrhea, dyspareunia, lower abdominal pain, abdominal discomfort and urge incontinence) displayed a statistically significant influence $(\mathrm{P}<0.05)$ in favor of the abused cases (Table 9).

Table 1: Age groups of the participants

\begin{tabular}{|c|c|c|c|c|c|c|c|}
\hline & \multicolumn{4}{|c|}{ All participants } & \multirow{3}{*}{ Chi square } & \multirow{3}{*}{$P$ value } \\
\hline & & \multicolumn{2}{|c|}{ Domestic violence } & \multicolumn{2}{|c|}{ Non domestic violence } & & \\
\hline & & $\mathrm{n}$ & $\%$ & $\mathrm{n}$ & $\%$ & & \\
\hline \multirow{5}{*}{ Age } & $<20$ & 25 & 16.9 & 127 & 20.1 & \multirow{5}{*}{34.17} & \multirow{5}{*}{$0.0001 *$} \\
\hline & 20-30 & 63 & 42.6 & 382 & 60.5 & & \\
\hline & 31-40 & 32 & 21.6 & 80 & 12.7 & & \\
\hline & $41-50$ & 21 & 14.2 & 31 & 4.9 & & \\
\hline & $51-60$ & 7 & 4.7 & 11 & 1.7 & & \\
\hline
\end{tabular}

n: number; * significant at $p<0.05$. 
Table 2: Marital status of the participants

\begin{tabular}{|c|c|c|c|c|c|c|c|}
\hline & \multicolumn{4}{|c|}{ All participants } & \multirow[t]{2}{*}{ Chi square } & \multirow{2}{*}{ p value } \\
\hline & & \multicolumn{2}{|c|}{ Domestic violence } & \multicolumn{2}{|c|}{ Non domestic violence } & & \\
\hline & & $\mathrm{n}$ & $\%$ & $\mathrm{n}$ & $\%$ & \multirow{5}{*}{53.03} & \multirow{5}{*}{$0.0001^{*}$} \\
\hline \multirow{4}{*}{$\begin{array}{c}\text { Marital } \\
\text { Status }\end{array}$} & Married & 83 & $56 \%$ & 487 & $77 \%$ & & \\
\hline & Single & 28 & $19 \%$ & 99 & $16 \%$ & & \\
\hline & Widow & 20 & $14 \%$ & 13 & $2 \%$ & & \\
\hline & Divorce & 17 & $11 \%$ & 32 & $5 \%$ & & \\
\hline \multicolumn{2}{|c|}{ Total } & 148 & $100 \%$ & 631 & $100 \%$ & & \\
\hline
\end{tabular}

$n:$ number; * significant at $p<0.05$.

Table (3): Socio-demographic data of the participants

\begin{tabular}{|c|c|c|c|c|c|c|}
\hline & \multicolumn{2}{|c|}{ Domestic violence (148) } & \multicolumn{2}{|c|}{ Non domestic violence (631) } & \multirow{2}{*}{ Chi square } & \multirow{2}{*}{ P value } \\
\hline & $\mathbf{n}$ & $\%$ & $\mathbf{n}$ & $\%$ & & \\
\hline \multicolumn{7}{|c|}{ Level of education } \\
\hline Elementary & 35 & 23.6 & 200 & 31.7 & 1.17 & $>0.05$ \\
\hline Intermediate & 60 & 40.5 & 105 & 16.6 & 20.5 & $0.001 *$ \\
\hline High & 35 & 23.6 & 226 & 35.8 & 2.4 & $>0.05$ \\
\hline More & 18 & 12.2 & 100 & 15.8 & 0.48 & $>0.05$ \\
\hline \multicolumn{7}{|c|}{ Occupation } \\
\hline Housewife & 65 & 43.9 & 170 & 26.9 & 4.06 & $0.03 *$ \\
\hline Employed & 83 & 56.1 & 461 & 73.1 & 2.23 & $>0.05$ \\
\hline \multicolumn{7}{|c|}{ pregnancy status } \\
\hline Yes & 37 & 25 & 102 & 16.2 & 1.89 & $>0.05$ \\
\hline No & 111 & 75 & 529 & 83.8 & 0.49 & $>0.05$ \\
\hline \multicolumn{7}{|c|}{ Number of children } \\
\hline Less than 2 & 30 & 20.3 & 126 & 20 & 0.002 & $>0.05$ \\
\hline $2-5$ & 77 & 52 & 328 & 52 & 0.002 & $>0.05$ \\
\hline More than 5 & 41 & 27.7 & 177 & 28.1 & 0.002 & $>0.05$ \\
\hline \multicolumn{7}{|c|}{ History of chronic diseases } \\
\hline Yes & 33 & 22.3 & 126 & 20 & 0.12 & $>0.05$ \\
\hline No & 115 & 77.7 & 505 & 80 & 0.03 & $>0.05$ \\
\hline \multicolumn{7}{|c|}{ History of drug taken for chronic diseases } \\
\hline Yes & 27 & 18.2 & 106 & 16.8 & 0.05 & $>0.05$ \\
\hline No & 121 & 81.8 & 525 & 83.2 & 0.01 & $>0.05$ \\
\hline
\end{tabular}

$n$ : number; * significant at $p<0.05$.

Table 4: Age groups of the partners

\begin{tabular}{|c|c|c|c|c|c|c|c|}
\hline & & \multicolumn{4}{|c|}{ All partners } & \multirow{3}{*}{ Chi square } & \multirow{3}{*}{$P$ value } \\
\hline & & \multicolumn{2}{|c|}{ Domestic violence } & \multicolumn{2}{|c|}{ Non domestic violence } & & \\
\hline & & $\mathbf{n}$ & $\%$ & $\mathbf{n}$ & $\%$ & & \\
\hline \multirow{5}{*}{ Age } & $<20$ & 20 & 13.5 & 86 & 13.6 & \multirow{5}{*}{8.46} & \multirow{5}{*}{$>0.05$} \\
\hline & $20-30$ & 68 & 45.9 & 292 & 46.3 & & \\
\hline & $31-40$ & 40 & 27.0 & 127 & 20.1 & & \\
\hline & 41-50 & 15 & 10.1 & 64 & 10.1 & & \\
\hline & 51-60 & 5 & 3.4 & 62 & 9.8 & & \\
\hline
\end{tabular}

n: number; * significant at $p<0.05$. 
Table 5: Socio-demographic data of the partners

\begin{tabular}{|c|c|c|c|c|c|c|c|}
\hline & & \multicolumn{2}{|c|}{$\begin{array}{l}\text { Domestic } \\
\text { violence }\end{array}$} & \multicolumn{2}{|c|}{$\begin{array}{c}\text { Non } \\
\text { domestic } \\
\text { violence }\end{array}$} & \multirow[t]{2}{*}{ Chi square } & \multirow[t]{2}{*}{$P$ value } \\
\hline & & $\mathbf{n}$ & $\%$ & $\mathbf{n}$ & $\%$ & & \\
\hline \multirow[t]{4}{*}{ Level of education } & Elementary & 105 & 70.95 & 250 & 40 & 8.87 & $0.01 *$ \\
\hline & Intermediate & 10 & 6.757 & 131 & 21 & 7.12 & $0.01 *$ \\
\hline & High & 15 & 10.14 & 130 & 21 & 3.56 & $>0.05$ \\
\hline & More & 18 & 12.16 & 120 & 19 & 1.5 & $>0.05$ \\
\hline \multirow[t]{2}{*}{ Smoker } & Yes & 102 & 68.92 & 438 & 69 & 0.001 & $>0.05$ \\
\hline & No & 46 & 31.08 & 193 & 31 & 0.003 & $>0.05$ \\
\hline \multirow[t]{3}{*}{ Income } & Low & 102 & 68.92 & 180 & 29 & 7.9 & $0.01 *$ \\
\hline & Moderate & 25 & 16.89 & 210 & 33 & 0.39 & $>0.05$ \\
\hline & Will & 21 & 14.19 & 241 & 38 & 1.18 & $>0.05$ \\
\hline \multirow[t]{2}{*}{ Previous custody } & Yes & 4 & 2.703 & 16 & 3 & 0.005 & $>0.05$ \\
\hline & No & 144 & 97.3 & 615 & 97 & 0.0001 & $>0.05$ \\
\hline \multirow[t]{3}{*}{ Employment } & Governmental & 55 & 37.16 & 350 & 55 & 3.61 & $>0.05$ \\
\hline & Private & 88 & 59.46 & 241 & 38 & 4.6 & $0.03 *$ \\
\hline & Jobless & 5 & 3.378 & 40 & 6 & 0.9 & $>0.05$ \\
\hline \multirow[t]{2}{*}{ History of chronic diseases } & Yes & 26 & 17.57 & 112 & 18 & 0.0009 & $>0.05$ \\
\hline & No & 122 & 82.43 & 519 & 82 & 0.0002 & $>0.05$ \\
\hline \multirow{2}{*}{$\begin{array}{l}\text { History of drug taken for } \\
\text { chronic diseases }\end{array}$} & Yes & 20 & 13.51 & 86 & 14 & 0.0004 & $>0.05$ \\
\hline & No & 128 & 86.49 & 545 & 86 & 0.00007 & $>0.05$ \\
\hline
\end{tabular}

n: number; * significant at $p<0.05$.

Table (6): Frequency of abusing, seeking help or not, and the Approach of help

\begin{tabular}{|c|c|c|c|c|c|}
\hline & & $\mathbf{n}$ & $\%$ & Chi square & P value \\
\hline \multirow{3}{*}{ Frequency of abusing } & Very often & 8 & 5.41 & \multirow{3}{*}{123.47} & \multirow{3}{*}{$0.0001^{*}$} \\
\hline & sometimes & 28 & 18.92 & & \\
\hline & Occasionally & 112 & 75.68 & & \\
\hline \multirow{2}{*}{ Seeking help or not (148) } & Yes & 43 & 29.05 & \multirow{2}{*}{25.97} & \multirow{2}{*}{$0.0001^{*}$} \\
\hline & No & 105 & 70.95 & & \\
\hline \multirow{5}{*}{$\begin{array}{c}\text { Approach of help } \\
\text { (43) }\end{array}$} & Family & 34 & 79.07 & \multirow{5}{*}{95.26} & \multirow{5}{*}{$0.0001^{*}$} \\
\hline & Friends & 5 & 11.63 & & \\
\hline & DOVs & 0 & 0 & & \\
\hline & Police & 2 & 4.65 & & \\
\hline & $\begin{array}{c}\text { Legal and/medicolegal } \\
\text { consequences }\end{array}$ & 2 & 4.65 & & \\
\hline
\end{tabular}

n: number; * significant at $p<0.05$, DVOs: Domestic Violence Organizations.

Table 7: sorts of physical violation among the abused cases

\begin{tabular}{|c|c|c|c|c|}
\hline Sorts of physical violation & $\mathbf{n}$ & $\mathbf{\%}$ & Chi square & P value \\
\hline Slap/push & 62 & 56.4 & & \\
\hline Punch, Kick & 47 & 42.7 & & \\
\hline Burns-scalds & 13 & 11.8 & \multirow{3}{*}{114.7} & \multirow{2}{*}{$0.0001^{*}$} \\
\hline Objects & 34 & 30.9 & & \\
\hline Hospital admission & 4 & 3.6 & & \\
\hline Permanent infirmity & 1 & 0.9 & & \\
\hline
\end{tabular}

$n$ : number; ${ }^{*}$ significant at $p<0.05$. 
Table 8: The probable perpetrators

\begin{tabular}{|c|c|c|c|c|}
\hline $\begin{array}{c}\text { The probable } \\
\text { perpetrators }\end{array}$ & $\mathbf{n}$ & $\mathbf{\%}$ & Chi-square & \multirow{2}{*}{ P value } \\
\hline Husband & 85 & 57.4 & & \\
\hline Father & 36 & 24.3 & & \multirow{2}{*}{111.17} \\
\hline Mother & 17 & 11.5 & & \\
\hline Sibling & 14 & 9.46 & & \\
\hline Others & 14 & 9.46 & & \\
\hline
\end{tabular}

n: number; * significant at $p<0.05$.

Table 9: Gynecological and urological symptoms in women (with and without history of domestic violence)

\begin{tabular}{|c|c|c|c|c|c|c|}
\hline & \multicolumn{2}{|c|}{$\begin{array}{c}\text { Domestic } \\
\text { violence }\end{array}$} & \multicolumn{2}{c|}{$\begin{array}{c}\text { Non Domestic } \\
\text { violence }\end{array}$} & \multirow{2}{*}{ Chi square } & \multirow{2}{*}{ P value } \\
\hline Manifestations & $\mathrm{n}$ & $\%$ & $\mathrm{n}$ & $\%$ & & \\
\hline Termination of pregnancy & 11 & 7.43 & 51 & 8.08 & 0.02 & $>0.05$ \\
\hline Vaginal bleeding & 40 & 27.03 & 55 & 8.7 & 9.38 & $0.01^{*}$ \\
\hline Dysmenorrhea & 30 & 20.27 & 49 & 7.7 & 5.57 & $0.01^{*}$ \\
\hline Dyspareunia & 45 & 30.41 & 88 & 13.9 & 6.10 & $0.03^{*}$ \\
\hline Fertility problem & 9 & 6.081 & 35 & 5.54 & 0.024 & $>0.05$ \\
\hline prolapse & 10 & 6.757 & 50 & 7.9 & 0.09 & $>0.05$ \\
\hline Vaginal pain & 5 & 3.378 & 21 & 3.3 & 0.0003 & $>0.05$ \\
\hline Lower abdominal pain & 62 & 41.89 & 138 & 21.8 & 6.28 & $0.04^{*}$ \\
\hline Abdominal discomfort & 70 & 47.3 & 100 & 15.8 & 15.66 & $0.01^{*}$ \\
\hline Bowel symptoms & 7 & 4.73 & 21 & 3.3 & 0.24 & $>0.05$ \\
\hline Dysuria & 13 & 8.784 & 59 & 9.3 & 0.01 & $>0.05$ \\
\hline Urinary frequency & 8 & 5.40 & 30 & 4.7 & 0.04 & $>0.05$ \\
\hline Stress incontinence & 7 & 4.73 & 23 & 3.6 & 0.14 & $>0.05$ \\
\hline Urge incontinence & 30 & 20.27 & 40 & 6.3 & 7.29 & $0.01^{*}$ \\
\hline mixed incontence & 5 & 3.37 & 19 & 3.01 & 0.02 & $>0.05$ \\
\hline
\end{tabular}

n: number; * significant at $p<0.05$.

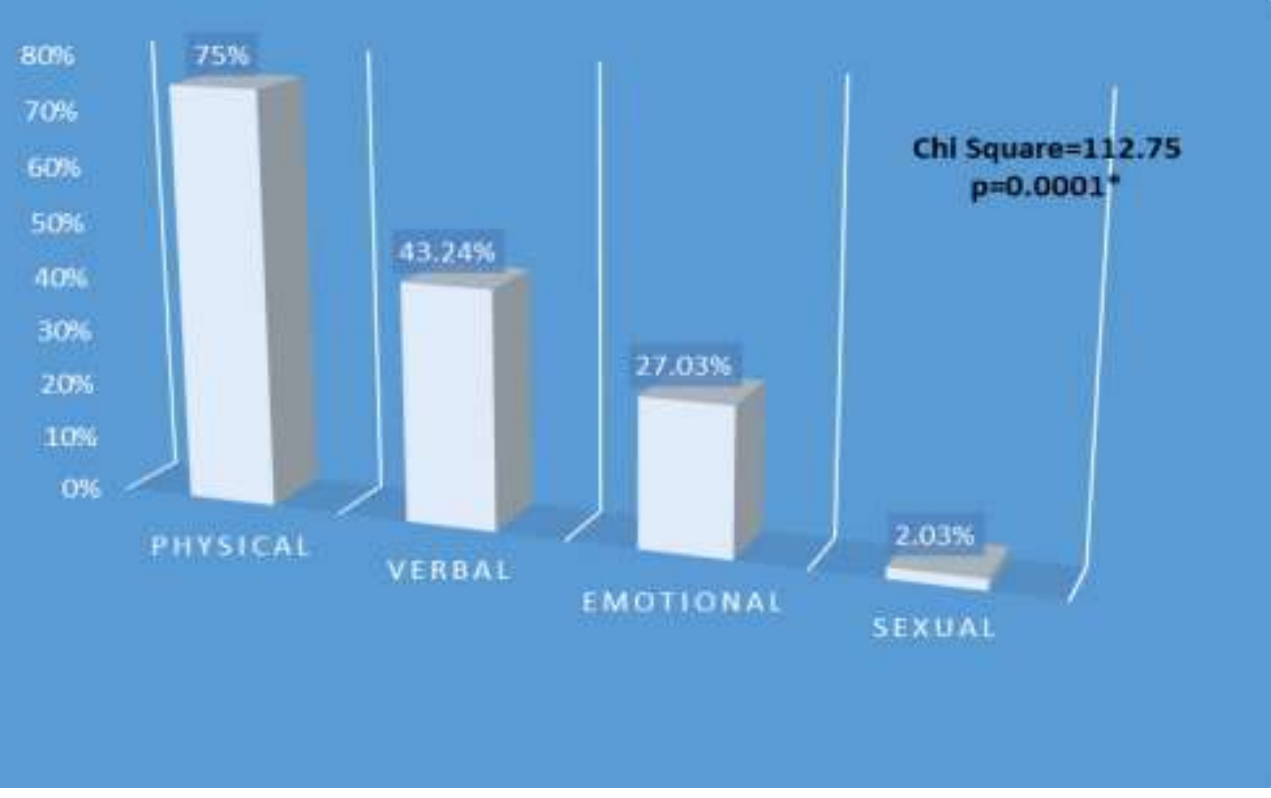

Figure (1): the prevalence and forms of violence for the study participants.

* Significant at $\mathbf{p}<\mathbf{0 . 0 5}$. 


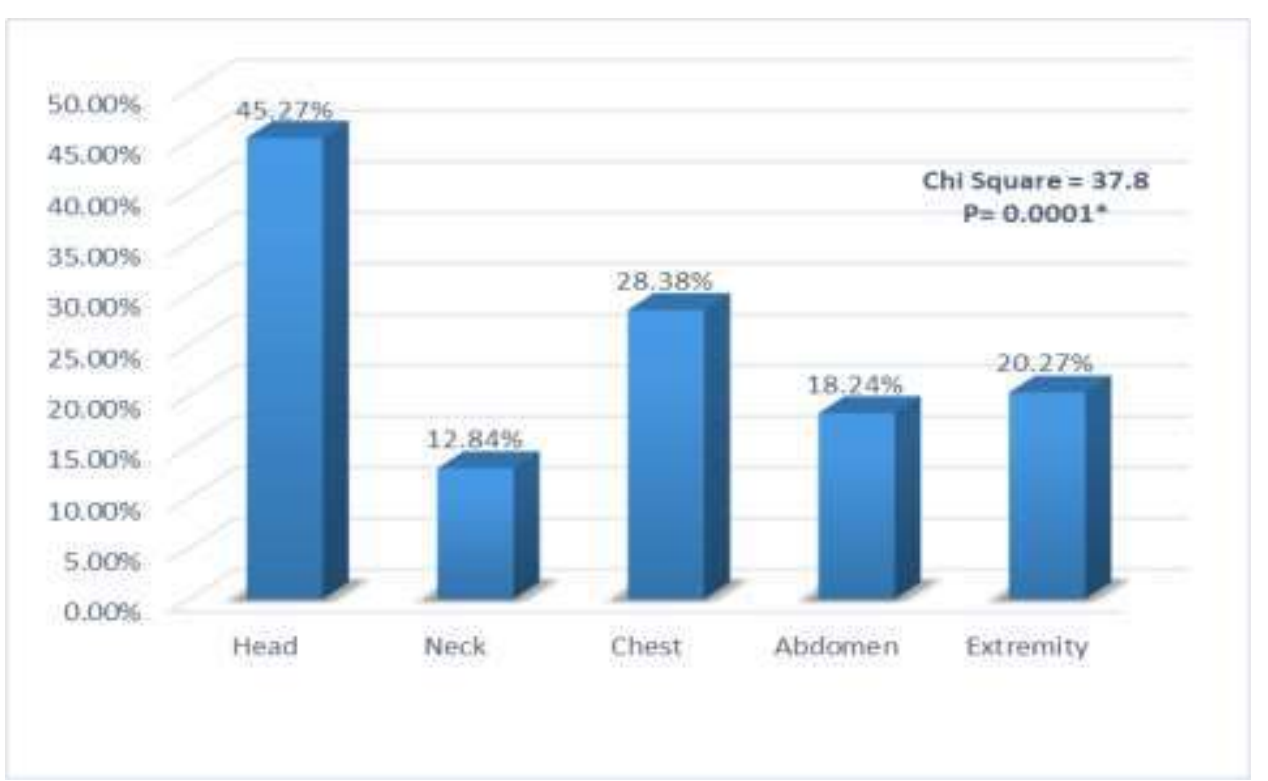

Figure (2): the topographic distribution of injuries.* Significant at $\mathrm{p}<0.05$.

\section{Discussion}

Over the last few years, the researches available on social and healthful impacts of domestic violence display a quick outgrowth. For many reasons, reporting of domestic violence in the developing countries is still a tricky process especially those governed by special constitutions and traditions (Afifi et al., 2011 and Halawi et al., 2017). Nevertheless, in these countries, violence against women begin to be a main health interest among health workers (Sethi et al., 2004 and Halawi et al., 2017).

Among the literature, only a few studies had converged on the correlation among abuses and any other accompanying physical and or psychological manifestations (Eisenstat and Bancroft, 1999). Moreover, the target set of the majority of these studies was at most children and adolescents with only a little focusing on women who experience domestic violence (Dearwater et al., 1998). Therefore, this study was conducted to explore the great importance of medicolegal practice that has a decisive role in a proper balance regulation between laws, public health, and police, and to estimate the predominance of domestic violence in a sample of women presenting with gynecological and / urological symptoms considering the possible risk factors.

In the current work, the response rate was (82\%).This result is almost similar to the announced percentage (88\%) by (Richardson et al., 2002) in their work on British women but considered lower in relation to others (92\%) (Schraiber et al., 2002) and (94\%) (Freund et al., 1996). Our results show that the prevalence of domestic violence in the study sample was (18.99\%). Different Percentages (41\% - 44.45\%) were reported in other studies from The United States (McCauley et al., 1995) and Spain (Marais et al., 1999). In the present study, the prevalence of physical violence was $75 \%$. This percentage is higher than the results found in different American surveys (Hamberger et al., 1992 and McCauley et al., 1995). This variation of prevalence rate might be due to cultural and ethnic factors as well as the variation in definition and magnitude of the problem among different populations (John et al., 2004).

As proved by the current findings, the age of the women may consider as a risk factor for domestic violence, where women from 20-30 years old are more prone to be victimized. This result coincides with that reported by (Habib et al., 2011) in Egypt and (Barnawi, 2017) in Saudi Arabia. Based on the results of this work, domestic violence against currently married women was more prevalent. These results go hand in hand with a Saudi Arabian study (Barnawi, 2017) but contradicting the previously published Iranian report about the predominant of divorced women as victims of abuse (S Pournaghash, 2011)

Apart from the intermediate level of education, socio-demographic characteristics of abused and nonabused women participated in this work showed no significant difference. This could be due to least sociodemographic variance among the participants as their education, and economic status shows minimal differences (Bates et al., 2004).

Another study from Haiti reported a high abuse rate among less educated women considering the victim's education standard as a predictor for domestic violence (Gage, 2005). Less than five years education period, noncompletion of the primary or the high school are considered as risk factors (Gage, 2005). In this study, the intermediate level of education was pointed out to be a potential risk factor for domestic violence with a significant predictive value. Literature indicates that women with a high level of education are more protective 
against abuse than the others (Stith et al., 2004 and Gage, 2005). This may be due to the direct protective influence of education that improves the general positive conduct toward violence (Stith et al., 2004).

In our study, it was proved that private jobs of the partners, elementary, and intermediate levels of education, as well as their low income were risk factors for abusing. Possibly, the stress of commerce in private sections may augment such risk especially if was accompanied with a low level of education. Likewise, studies on the partners' risk factors of domestic violence showed the same result (Hamby, 2014 and Sahar et al., 2016).

In the current work, the frequency of abusing shows a significantly higher percentage of occasional situations $(75.68 \%)$, while the percentages of sometimes and very often situations were $(18.92 \%$ and $5.41 \%$ respectively) with a statistically significant result. Among the literature, various results were announced (Stith et al., 2004 and Barnawi, 2017).

The most commonly encountered anatomical site culminates trauma in the existing study was the head (45.27\%) followed by the chest (28.83\%). This data was coinciding with a previously published Saudian data with variable percentages (Halawi et al., 2017). On the contrary, previous study from Serbia, investigating the topographic distribution of the injuries in domestic violence had reported an increased incidence of extremities' injuries more than those of the chest (Djikanović et al., 2012).This topographic difference may be due to variation in the pattern of trauma and the surrounding circumstances.

As for the sort of physical abuse, (56.4\%) of the participants in this study revealed having injuries in the form of slap/push. The least incidence was for the burns and scalds (11.8\%). This result goes hand in hand with a study achieved by (Halawi et al., 2017) on Saudi Arabian females from thirteen governorates of Saudi Arabia reporting (45.6\%) for slap/push and (4.3\%) for burns and scalds as the minor incidence. Approximate percentages was announced by (Fanslow and Robinson, 2010) in their work on participants from New Zealand. About (3.6\%) of our cases gave a history of hospital admission because of dry burn and only one case $(0.9 \%)$ reported a permanent infirmity as a result of a direct kick to the right eye.

In the present research, the main perpetrators were husbands (57.4\%) and combined father and mother (35.8\%). This high incidence may be explained by the high number of married women participate in the study. Moreover, singles were numerically more than widow and divorced women. Ex-boyfriends, boyfriends were believed as the main perpetrators in another study from North of England (John et al., 2004).These different results seem to be because of cultural and ethnic factors.

As proved in the existing results, (29.05\%) of cases were seeking help, the highest direction of help was the family (79.07\%). The police was encountered only in
(4.65\%) of cases and no cases were reported to DVOs. This relatively low incidence of cases reporting their abuse to the formal institutes may be due to the cultural principles that assert domestic violence as clandestine family issues (Maartje et al., 2016). Fearing of unfavorable outcomes of seeking help as well as insufficient trusting in institutions may be a probable other explanation (Lagdon et al., 2014).

In a study conducted on Serbian women to identify their approach for help in case of domestic abuse, about (22\%) of the participants had ever sought help. The approach for help was either the police or the Domestic Violence Organizations (DVOs), (12\% and 10\% respectively) (Mamdouh et al., 2012). Other work from Netherlands reported a higher percentage of cases asking for help (75\%). Informal origins for help (family and friends) were most frequently acquainted than the formal institutes such as police, DOVs (Lo Fo et al., 2007).

Ten gynecological and five urological symptoms had been inspected in the questionnaires employed in this work. Particular gynecological symptoms (Vaginal bleeding, dysmenorrhea, dyspareunia, lower abdominal pain, and abdominal discomfort) were significantly more reported in women with domestic violence. Similarly, a study from Spain (Maria et al., 2014) reported such findings. From the five urological symptoms, only urge incontinence shows a significant difference. This result was in accordance with (Lai et al., 2016) in their work on American females.

Several studies showed that women with a history of domestic violence notified gynecological and/ urological problems three times more than the nonabused (Han and Stewart, 2014). As reported in the literature, domestic violence was prominent with variable degrees in women presenting gynecological and / urological clinics (Lai et al., 2016). Women with a history of domestic violence were more possibly to seek medical help with recurrent complains of lower abdominal discomfort, dyspareunia, dysmenorrhea, bowel manifestations, mixed urinary incontinence and pregnancy troubles as well as disquiet about developing malignancies (Maria et al., 2014).

The correlation between domestic violence and the significantly reported gynecological and/urological symptoms may be due to anxiety, and psychological stress that notarized to be one of the predisposing factors for the dysregulation in the hypothalamic-pituitary axis (HPA) ( Nanthana and Vongsirimas,2014). This dysregulation appears to be more prominent in chronic rather than short-term stress (Lai et al., 2016).This possibility had been supported by the reported higher level of evening cortisol and morning and evening dehydroepiandrosterone among women with a history of abuse (Maria et al., 2014). Similar results were reported in cases with history of abuse throughout childhood ( Nanthana and Vongsirimas,2014). 
As in any field study, the present work may show some limitations. The medicolegal data obtained from a questionnaire studies are fewer if compared with either obtained from hospital admitted cases or those subjected to autopsy. The actual prevalence of the problem might be underestimated or overestimated because of the probable bias in participant' statements. The samples used in the study were representative only for women who look up for health supports

On the other hand, this work provides a significant fundamental information on this important health matter. The sample size was large to the extent that considered as a strength aspect of the study. To the best of knowledge, this is the foremost publication concerning the possible association of domestic violence with the history of both gynecological and urological manifestations. In addition, the combination of forensic aspect together with social aspect in one work may add to the literature a cornerstone study upon it, further investigations may be built up.

\section{Conclusion and recommendations}

A proper training for healthcare providers for the appropriate use of trauma forensic survey sheet must be included as influential training programs, this sheet might be of great medicolegal significance for reporting the actual patients' complains, identifying the injuries, and keep evidences safe. Incorporating a well-trained forensic medicine specialist as a member of family violence organizations' team must come into action. The awareness' programs concerning all aspects of domestic violence should possess a significant area of global public enlightenment. Family physicians have to consider cases of domestic violence in women with certain gynecological and / urological manifestations. Further studies are recommended for a better realization of the relation between physical and emotional upsets in domestic violence cases.

\section{Acknowledgment}

The authors are very grateful to all women who participate in this study, and to the administrative affairs of all health centers.

\section{Disclosure statement}

There are no conflicts of interest.

\section{References}

Abramsky T, Watts CH, Garcia-Moreno C, et al., (2011): What factors associated with recent intimate partner violence? Findings from the WHO multi-country study on women's health and domestic violence. BMC Public Health.11:109. http://dx.doi.org/10.1186/1471-2458-11-109.

Afifi ZE, Al-Muhaideb NS, Hadish NF et al., (2011): Domestic violence and its impact on married women's health in Eastern Saudi Arabia. Saudi Med J. 32: 612-620.

Ahmad Hamad Al Dosary (2016): Health Impact of Domestic Violence against Saudi Women: Cross
Sectional Study. International Journal of Health Sciences, Qassim University.10 (2):165-173.

Akadli Ergoçmen B, Yüksel-Kaptanoglu I, and Henrica AFM Jansen (2013): Intimate partner violence and the relation between help-seeking behavior and the severity and frequency of physical violence among women in Turkey. Violence against women. 19:1151-74.

Amanda M Stylianos (2018): Economic Abuse Experiences and Depressive Symptoms among Victims of Intimate Partner Violence. Journal of Family Violence.33(5):1-12.

Barnawi FH (2017): Prevalence and risk factors of domestic violence against women attending a primary care center in Riyadh, Saudi Arabia. Journal of interpersonal violence. 32: 11711186.

Bates LM, Schuler RS, Islam F et al., (2004): Socioeconomic factors and processes associated with domestic violence in rural Bangladesh. Int Fam Plan Perspec. 30:190-9.

Borchers A, Lee RC, Martsolf DS et al., (2016): Employment maintenance and intimate partner violence. Workplace Health Safe. 64 (10):469478.

Boyle MH, Georgiades K, Cullen J et al., (2009): Community influences on intimate partner violence in India: Women's education, attitudes towards mistreatment and standards of living. Soc Sci Med. 69:691-7.

Crane DR, Middle KC, and Bean RA (2000): Establishing criterion scores for the Kansas marital satisfaction. Am J Fam Ther. 28:53-60.

Dawson SB and Trapp R (2001): Basic and clinical biostatics. McGrow Hill McGrow Hill Medical Publishing Division. 3rd ed. 2001: 212-220.

Dearwater SR, Coben JH, Campbell JC et al., (1998): Prevalence of intimate partner abuse in women treated at community hospital emergency departments. JAMA. 280: 433 - 438.

Djikanović B, Wong SL, Jansen HA et al., (2012): A Help-seeking behaviour of Serbian women who experienced intimate partner violence. Fam Pract. 29(2):189-95.

Eisenstat SA and Bancroft L (1999): Domestic violence. N Engl J Med. 341: 886 - 892.

Fanslow JL, and Robinson EM (2010): Help-seeking behaviors and reasons for help seeking reported by a representative sample of women victims of intimate partner violence in New Zealand. J Interpers Violence. 25(5):929-51.

Freund KM, Bak SM, and Blackhall L (1996): Identifying domestic violence in primary care practice. J Gen Intern Med.11: 44 - 46.

Gage AJ (2005): Women's experience of intimate partner violence in Haiti. Soc Sci Med. 61:343-64.

Habib SR, Abdelazim EK, Fawzy IA et al., (2011): Prevalence and effect of violence against 
women in Mina Governorate, Egypt. Journal of Forensic Science. 56:1521-27.

Haj-Yahia MM, Wilson RM, and Naqvi SA. (2012): Justification, perception of severity, harm, and criminalization of wife abuse in the Palestinian society. J Interpers Violence. 27: 1932-1958.

Halawi Azhar Ahmed, Almalki Zahrah Abid, Ahmed Alsadah et al., (2017): Prevalence and Risk Factors for Abuse among Saudi Females, KSA. The Egyptian Journal of Hospital Medicine. 68 (1): 1082-87.

Hamberger LK, Saunders DG, and Hovey M (1992): Prevalence of domestic violence in community practice and rate of physician enquiry. Fam Med. 24(4): 283 - 287.

Hamby S (2014): Intimate Partner and Sexual Violence Research: Scientific Progress, Scientific Challenges, and Gender. Trauma Violence Abuse.15 (3):149-158.

Han A and Stewart DE (2014): Maternal and fetal outcomes of intimate partner violence associated with pregnancy in the Latin American and Caribbean region. Int J Gynaecol Obstet. 124: 6-11

Heim C, Newport JN, Heit S et al., (2000): PituitaryAdrenal and autonomic responses to stress in women after sexual and physical abuse in childhood. JAMA. 284(5): 592- 597.

John R, Johnson JK, Kukreja S et al., (2004): Domestic violence: prevalence and association with gynecologic symptoms. BJOG.10: 1128 - 1132.

Jury A, Thorburn N and Weatherall R (2017): What's his is his and what's mine is his: Financial power and economic abuse in Aotearoa. Aotearoa New Zealand Social Work. 29(2):69-82.

Kotelchuck M (2006): Pregnancy Risk Assessment Monitoring System (PRAMS): possible new roles for a National MCH Data System. Public Health Rep .121:6-10.

Lagdon S, Armour C, and Stringer M (2014): Adult experience of mental health outcomes as a result of intimate partner violence victimisation: a systematic review. Eur J Psychotraumatol. 5: 112.

Lai HH, Morgan CD, Vetter J et al., (2016): Impact of childhood and recent traumatic events on the clinical presentation of overactive bladder. Neurourol Urodyn. 35(8):1017-23.

Lo Fo Wong S, Wester F, Mol S, et al.,( 2007): Utilisation of health care by women who have suffered abuse: a descriptive study on medical records in family practice. Br J Gen Pract. 57: 396-400.

Maartje J W Loeffen, Lo Fo Wong, Fred P J F Wester et al., (2016): Are gynaecological and pregnancyassociated conditions in family practice indicators of intimate partner violence? Family Practice. 33 (4): 354-359.
Mamdouh HM, Ismail HM, Kharboush IF et al., (2012): Prevalence and risk factors for spousal violence among women attending health care centres in Alexandria, Egypt. East Mediterr Health J. 18: 1118-1126.

Marais A, de Villiers PJT, Moller AT et al., (1999): Domestic violence in patients visiting general practitioners - prevalence, phenomenology, and association with psychopathology. S Afr Med J. 89: $635-640$.

Maria A. Pico-alfonso, Isabel Garciaet et al., (2014): Changes in Cortisol and Dehydroepiandrosterone in women victims of physical and psychological intimate partner violence. Bio Psychology. 56: 233-240.

McCauley J, Kern DE, Kolodner K et al., (1995): The "battering syndrome": prevalence and clinical characteristics of domestic violence in primary care internal medicine practice. Ann Intern Med. 123: 737 - 746.

Nanthana T and Vongsirimas N (2014): Examining Mediators of Intimate Partner Violence and Depressive Symptoms among Thai Women with Gynecological Problems. Pacific Rim Int J Nurs Res. 18(3) 216-227.

Richardson JO, Petruckevitch A, Moorey S et al., (2002): Identifying domestic violence: cross-sectional study in primary care. BMJ. 324: $247-260$.

Rickert VI, Wiemann CM, Harrykissoon SD et al., (2002): The relationship among demographics, reproductive characteristics, and intimate partner violence. Am J Obstet Gynecol.187:1002-7.

S Pournaghash-Tehrani (2011): "Domestic violence in Iran: a literature review," Aggression and Violent Behavior. 16(1):1-5.

Sahar Ali Sari, Amal mohammed Qasem, and Samah Omar alfahl (2016): Domestic Violence: Prevalence among Saudi Women Attending Primary Health Care Centers in Al-Madina Al Monawara City. Int J Med Re .2: 18-28.

Saltzman LE, Johnson CH, Gilbert BC, et al., (2003): Physical abuse around the time of pregnancy: an examination of prevalence and risk factors in 16 states. Matern Child Health J.7:31-43.

Schraiber LB, d'Oliveria AF, Franca I Jr et al., (2002): Violence against women: a study in a primary health-care unit. Rev Saude Publica.4: 470 477.

Sedziafa AP, Tenkorang EY, Owusu AY et al., (2017): Women's experiences of intimate partner economic abuse in the Eastern Region of Ghana. Journal of Family. Issues. 38 (18): 2620- 2641.

Sethi D, Watts S, Zwi A, et al., (2004): Experience of domestic violence by women attending an inner city accident and emergency department. Emerg Med J. 21: 180 - 184. 
Stith SM, Smith DB, Penn CE et al., (2004): Intimate partner physical abuse perpetration and victimization risk factors: a meta-analytic review. Aggress Violent Beh. 10:65-98.

Swahnberg IM and Wijma B (2003): The NorVold Abuse Questionnaire (NorAQ) Validation of new measures of emotional, physical, and sexual abuse, and abuse in the health care system among women. Eur J Public Health.13:361-6.

Tashkandi A and Rasheed FP (2009): Wife abuse: a hidden problem. A study among Saudi women attending PHC centres. East Mediterr Health J. 15: $1242-1253$.

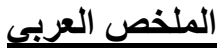

العنف المننلي المسبب لمعضلات خاصه بأمراض النساء والمسالك البولية: المنظور الطبي الشرعي والاجتماعي

\section{أبو اليزيد أحمد فؤاد' و سيد إبر اهيم على و محمد جابر سليمانَّ و أميره عقود عثمان؛}

يعتبر العنف المنزلي قضية صحية واجتماعية رئيسية وقد يكون لتوثيق الطب الشرعي لهذه المشكلة أهمية قصوى.

المدف من البحث: تمدف هذه الدراسة إلى تحديد وتعريف السمات الطبية الشرعية والاجتماعية للعنف المنزلي في مجموعة من

النساء اللاتي يعانين من اعراض خاصة بأمراض النساء وأمراض المسالك البولية أو أحدهما.

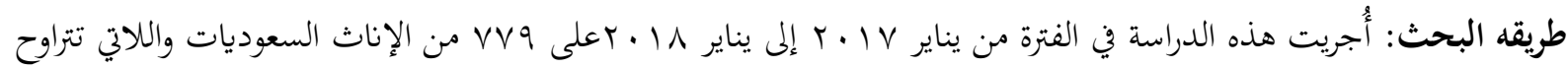

أعمارهن ما بين ها و . 7 سنة في عيادات أمراض النساء والتوليد وعيادات أمراض المسالك البولية في ثلاثة مراكز صحية ثانوية في المنطقة

الشرقية، المملكة العربية السعودية. وقد تم استخدام استبيان ذاتي في هذه الدراسة يتكون من جزئيين. الأول خاص بالبيانات الديموغرافية

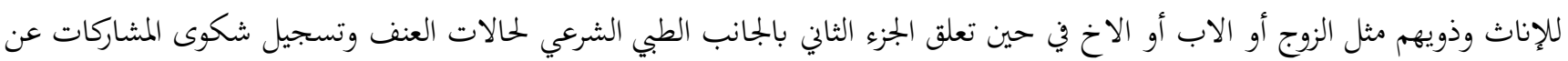
عشرة أعراض شائعه خاصه بأمراض النساء وخمسه أعراض شائعه خاصه بأمراض المسالك البولية.

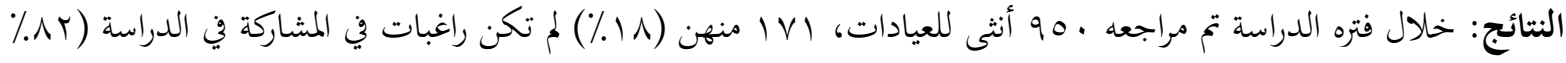
معدل استجابة). كانت النسبة المئوية للعنف البدني أعلى من الأشكال الأخرى (V0٪) مع نتيجة ذات دلالة إحصائية كما سجلت النساء

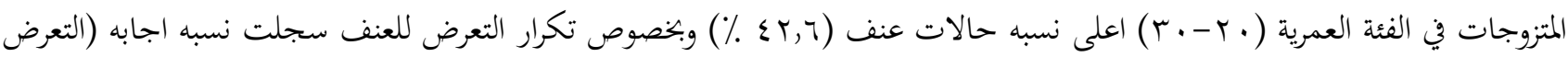

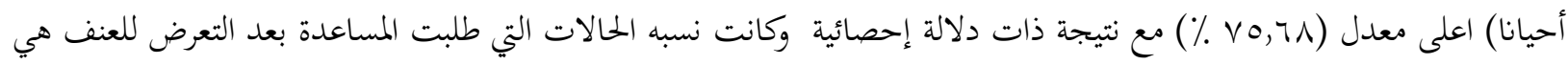

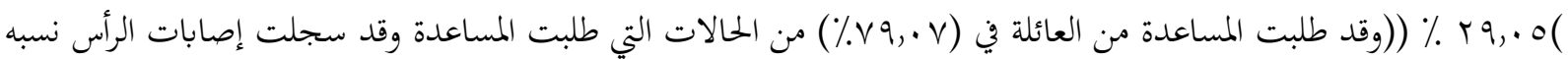

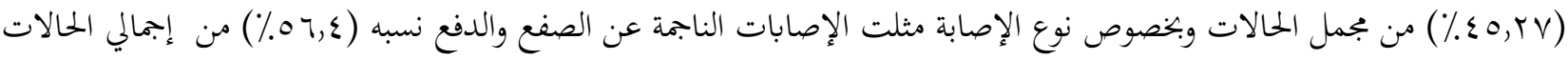

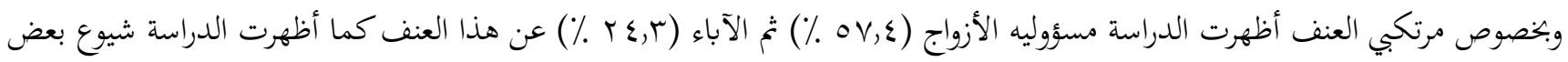
الاعراض بين النساء اللاتي تعرضن للعنف كالنيف المهبلي ، وعسر الطمث ، وعسر الجماع ، وآلام أسفل البطن ، والاحساس بعدم الراحة في منطقه البطن والسلس البولي.

الاستنتاج: أظهرت الدراسة الحالية الأهمية القصوى للفحص الطبي الشرعي المبدئي في حالات العنف ضد النساء وخلصت المى

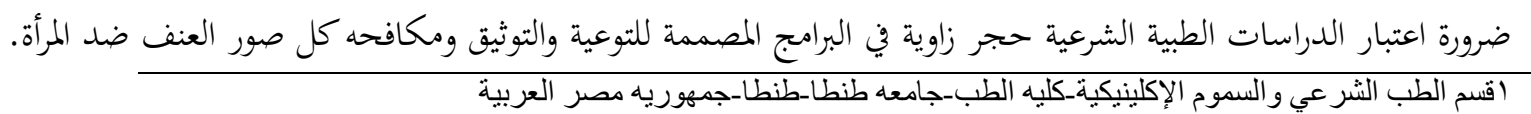

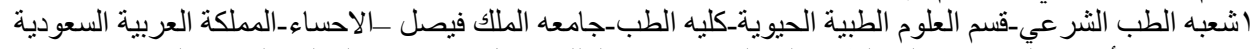

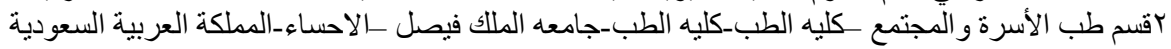

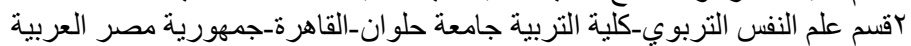

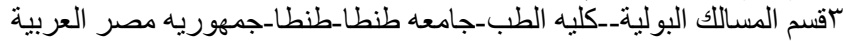
كقسم امر اض النساء والتوليد-كليه الطب_كليه الطب-جامعه الملك فيصل ـالاحساء_المملكة العربية السعودية 